\title{
Splenic metastasis from recurrent chromophobe renal cell carcinoma 12 years post-nephrectomy: a case report
}

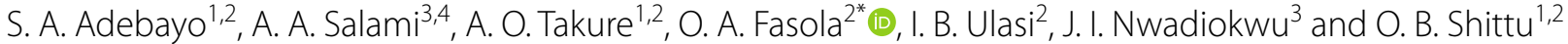

\begin{abstract}
Background: Renal cell carcinoma metastases to the spleen are rare. At the time of this report, only 20 cases of splenic metastases from RCC have been published in the literature. To our knowledge, our report is the first splenic metastasis from a chromophobe RCC.
\end{abstract}

Case presentation: A 44-year-old woman presented with clinical and radiological features of splenic metastasis from RCC, 12 years after radical nephrectomy for chromophobe RCC. Computed tomography, laparotomy and splenectomy revealed metastases to the spleen and retroperitoneal lymph nodes.

Conclusion: Splenic metastasis from RCC is uncommon, and rarer still from a chromophobe subtype of RCC. Surgical management of the metastasis is recommended.

Keywords: Chromophobe, RCC, Metastases, Splenic tumor

\section{Background}

Renal cell carcinoma (RCC) is a common malignancy of the kidney, usually diagnosed serendipitously when patients undergo abdominal imaging for other conditions [1]. RCC has several histopathological subtypes which are clear cell, papillary and chromophobe RCC (chRCC). It may spread locally or present as metastatic disease to distant organs, common sites being the lungs, the liver and bones. It rarely metastasizes to the spleen [2]. We report a case of a metachronous recurrence of a left chromophobe RCC to the spleen, 12 years after excision of the primary tumor, a rarity that we could not find any report of in the English literature.

\section{Case presentation}

A.A. is a 44-year-old female who presented with recurrent flank pain of 2-year duration, with associated weight loss and anorexia. The pain was dull aching, insidious

*Correspondence: fasola.oluwatobi@yahoo.com

2 Department of Surgery, University College Hospital, Ibadan, Nigeria

Full list of author information is available at the end of the article onset, radiated to the back, and with no known aggravating or relieving factors. There was no haematuria.

Twelve years earlier, she had similar symptoms with associated left flank swelling. Abdominal computerized tomography $(\mathrm{CT})$ at the time revealed a contrast-enhancing left renal tumor. A left radical nephrectomy was performed. The resected kidney then measured $16 \mathrm{~cm}$ $\times 10 \mathrm{~cm} \times 10 \mathrm{~cm}$ and weighed 1450 gram. The histology was that of chromophobe renal cell carcinoma (Furman's grade 3) (Fig. 1). She had no adjuvant treatment, but was reviewed regularly in the outpatient clinic in the first 5 years post-nephrectomy undergoing clinical physical examination and abdominal ultrasonography scan, on each occasion.

She never smoked tobacco cigarettes nor took alcohol. She is a clerk in a government establishment, and she had no history of prior exposure to industrial chemicals. There was no family history of similar cancer. She is married and has 2 children, both delivered through caesarean sections. She was not hypertensive and didn't have diabetes mellitus. 

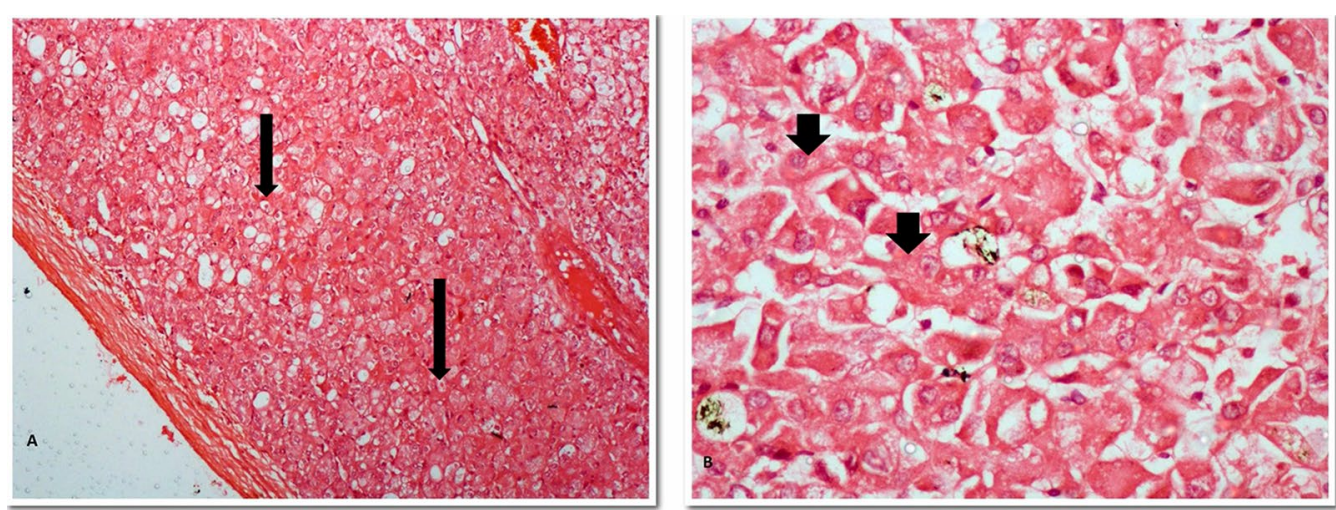

Fig. $1 \mathrm{H} \& \mathrm{E}$ stain $\times 100$ for $(\mathbf{a})$ and $\times 400$ for $(\mathbf{b})$ showing photomicrographs of the renal tumor showing sheets of malignant cells with eosinophilic cytoplasm (a). b Some of the cells have a 'flocculent' eosinophilic cytoplasm while others show a perinuclear halo and binucleation (long arrows). There are a few crumpled-looking hyperchromatic nuclei while many of the cells show vesicular nuclei with prominent nucleoli (short arrows)

Physical examination revealed an emaciated middleaged woman. She was pale, but afebrile, anicteric and with no peripheral lymph node enlargement. Systemic examination findings were normal aside left subcostal scar of previous nephrectomy and scar of previous Pfannenstiel incision. A clinical diagnosis of a recurrent left renal cell carcinoma was made.

Abdominal computerized tomography scan revealed a fairly rounded heterogenous, contrast enhancing mass with mixed density in the left hypochondrium, appearing to extend from the left renal bed, measuring $7.5 \times 7.6 \times 7.1 \mathrm{~cm}$. The mass had multiple central areas of hypodensity but no calcification. It appeared to be continuous with the spleen. There were no lymphadenopathies or ascites (Fig. 2).

She was anemic with haematocrit of $29 \%$, but had normal white cells and platelet counts. Her serum electrolytes, urea and creatinine, liver function test and clotting profile, were normal.

Following pre-operative optimization of her clinical condition including correction of anemia with red cell transfusion, she underwent exploratory laparotomy through an upper abdominal midline incision. A careful but daunting adhesiolysis was performed following which the following findings were appreciated: no peritoneal seedlings nor ascites or liver metastasis, left renal bed grossly free of tumor, an enlarged spleen with a centrally placed mass measuring about $5 \mathrm{~cm} \times 4 \mathrm{~cm}$, (Fig. 3), an enlarged retroperitoneal lymph node, and normal right kidney. Total splenectomy and excision of the enlarged retroperitoneal lymph node was then carried out. During splenectomy, the spleen was mobilized gently to prevent breaching of its capsule and tumor
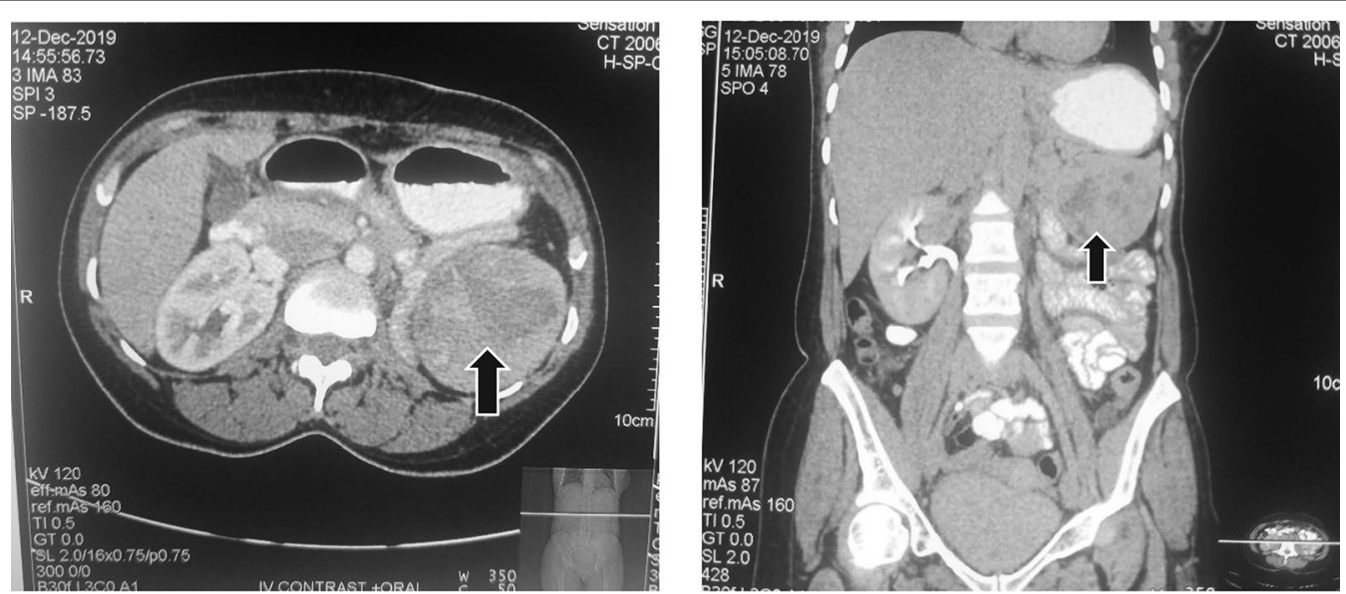

Fig. 2 a Axial CT of the abdomen showing contrast enhancing left hypochondrial mass and $\mathbf{b}$. coronal section of the same abdomen (solid arrows) 


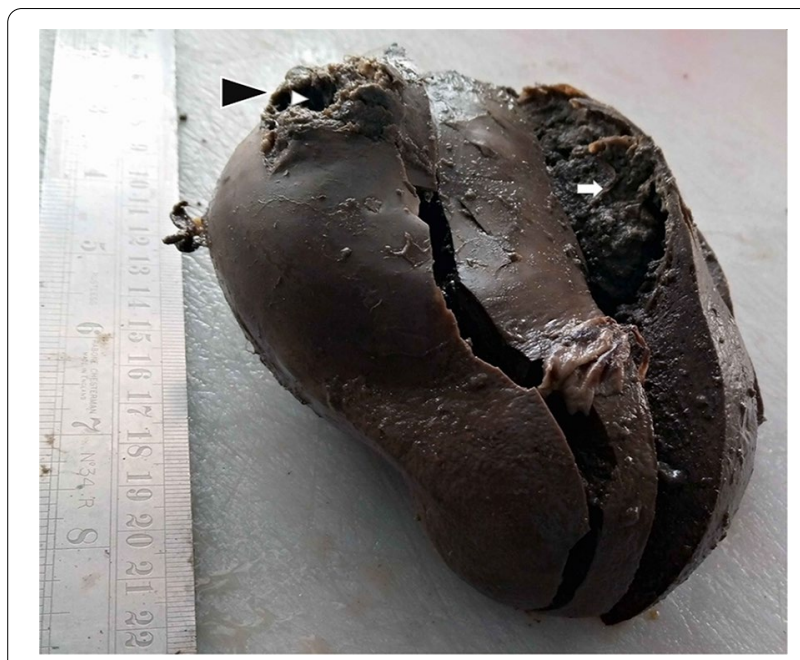

Fig. 3 Gross picture of the spleen with a cystic cavity containing tumor (arrow) and necrotic material. a focal area of rupture by the tumor is seen (arrowhead) spillage. Adequate haemostasis was secured. Estimated blood loss was about $360 \mathrm{ml}$.

On account of persistent unexplained intra-operative hypotension that extended to immediate post-operative period, and clinical features in keeping with adult respiratory distress syndrome, she was admitted into the intensive care unit for ionotropic support and mechanical ventilation. She was extubated on the 5 th post-operative day and transferred to the ward, where she had polyvalent vaccine for Streptococcus pneumoniae, Neisseria meningitidis and Haemophilus influenza during her recovery. She made steady clinical improvement culminating in her discharge from in-hospital care on postoperative day 24. Histology of the splenic mass (Fig. 4) and retroperitoneal lymph node (Fig. 5) revealed a metastatic renal cell carcinoma.

She has had 44 Gy of external beam radiotherapy to the renal and splenic bed in 22 fractions. Planned targeted therapy with sorafenib could not be given due to unaffordability of the drug by the patient. Abdomino-pelvic ultrasonography and CT scan done at 6 months after the laparotomy showed no evidence of tumor recurrence.
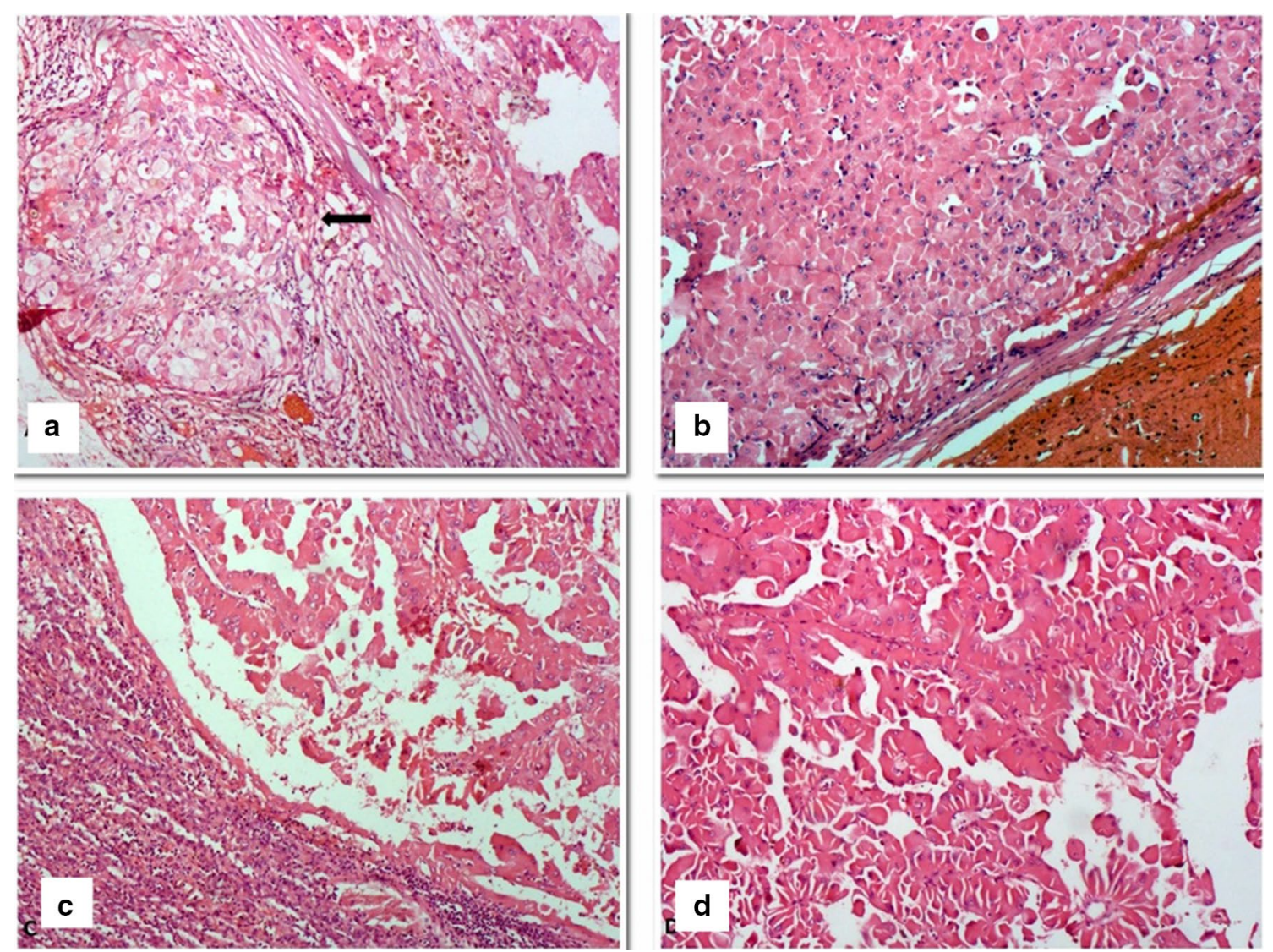

Fig. 4 H \& E stain $\times 100$ showing Photomicrographs of metastatic chromophobe renal cell carcinoma. The cells are similar to the primary tumor in the kidneys. There is a capsular rupture with nests of tumor cells outside of the splenic capsule (arrow) 


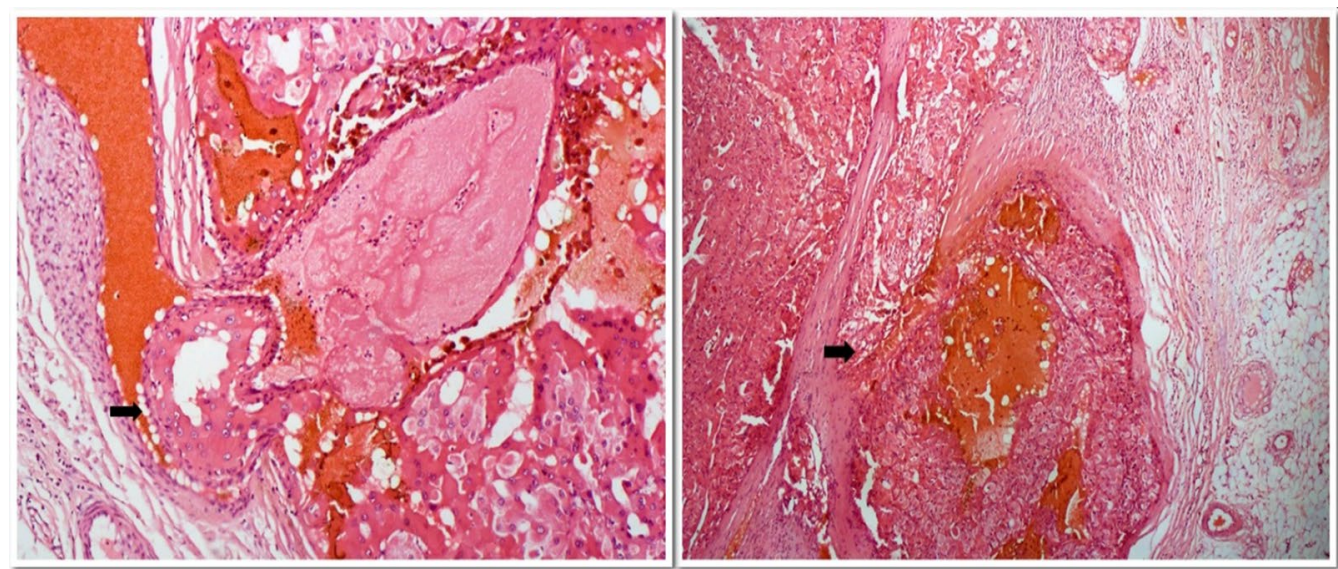

Fig. 5 H\& E stain $\times 100$ showing sections of the lymph node with tumor infiltration into blood vessels (arrows)

Her follow-up period-now at 12 months-has remained uneventful. Informed consent was obtained from the patient to write and publish this case report.

\section{Discussion}

RCC is a common type of renal cancer, accounting for about $80 \%$ of primary renal cancers [3]. Chromophobe histologic subtype accounts for $5 \%$ of RCCs, and they have better prognosis than the more common clear cell subtype [4]. The initial clinical and radiologic picture of the index case was suggestive of a local recurrence of the chromophobe renal cell carcinoma of 12 years earlier. The long time to recurrence is consistent with the biology of chromophobe RCC. Ismail et al. previously described a case of a 15-year local recurrence of chromophobe RCC in a 57-year-old woman who had T1b disease [5]. Our patient, however, presented as a metastasis in a splenic mass.

Yip et al. in a retrospective analysis found that, of 4,970 patients with metastatic RCCs, only $2.2 \%$ were of the chromophobe subtype [6]. RCCs would commonly metastasize to the lungs, bone, liver, and adrenal gland, while chRCC more commonly metastasizes to the liver [7]. Splenic metastases are uncommon. Theories explaining the relative rarity of splenic metastasis include: mechanical factors impeding implantation of tumor emboli such as constant flow, sharp angle of splenic artery branching from the celiac trunk, lack of afferent lymphatic vessels and the anti-tumor activity of the lymphoid tissue in the spleen [8].

A literature search on PubMed and MedLine with keywords such as splenic metastases, renal/kidney RCC metastases to the spleen was performed. At the time of writing this report, and to the best of our knowledge, there have been only 20 published reports of RCC metastases to the spleen, in the literature (Table 1) [927]. Of the reports, most primaries were clear cell RCCs, only a few were of the papillary RCC subtype. To our knowledge, our report if eventually published will be the first splenic metastasis from chromophobe RCC in the English literature, hence the uniqueness of this case report.

Total or partial splenectomy are surgical options for solitary splenic metastasis, especially in symptomatic patients with pain like the index case, and to prevent tumor rupture with bleeding, a potential but rare complication, with resection alone being sometimes successful. The rationale for total splenectomy in this case was the central location of the tumor in the spleen. Routine pre-operative preparation for total splenectomy, including pre-operative vaccinations, was not done because we thought the recurrent tumor was at the renal bed; splenic involvement was detected only at surgery. She, however, had the necessary vaccinations within 2 weeks of the splenectomy, with the plan for subsequent booster doses in future as recommended.

Though there is availability of local expertise and equipment for laparoscopic splenectomy, this was not considered in this case, again because we did not consider splenectomy as a component of the operation in the planning stage. Even if splenectomy was planned, previous surgeries with their attendant adhesions in a nonvirgin abdomen would have contraindicated laparoscopic approach.

Some authors have advocated employing the histologic appearance, the binucleation, 'raisinoid' nuclear appearance and perinuclear halo, in making the diagnosis of the tumor [29]. Some of these features are seen in the index case, both in the primary renal tumor as well as in the metastatic tumor. In addition to the well-known 
Table 1 Literature review of published case reports of splenic metastases from RCC

\begin{tabular}{|c|c|c|c|c|c|c|}
\hline Study & Age $(y r) / s e x$ & Primary histology & Time to metastasis & Primary side & Outcome & Met size \\
\hline Strum [10] & $59 / \mathrm{M}$ & NS & $22 \mathrm{yr}$ & Right & Dead after 5 years & NA \\
\hline Ishida et al. [13] & $50 / \mathrm{M}$ & NS & $7 \mathrm{yr}$ & Left & Alive for 6 years & $4 \mathrm{~cm}$ \\
\hline Nabi et al. [12] & $50 / F$ & NS & Synchronous & Left & Alive for 6 months & NA \\
\hline Kugel et al. [23] & $72 / M$ & Clear cell & $2 \mathrm{yr}$ & Left & Dead after 1 year & $8 \mathrm{~cm}$ \\
\hline McGregor et al. [22] & $65 / M$ & Papillary & Synchronous & Left & NA & $8 \mathrm{~cm}$ \\
\hline Shuck-Bello et al. [14] & $74 / M$ & Clear cell & $15 \mathrm{yr}$ & Right & NA & NA \\
\hline lelpo et al. [19] & $82 / M$ & NS & $14 \mathrm{yr}$ & Left & Alive for 15 months & $6 \mathrm{~cm}$ \\
\hline Moir et al. [20] & $70 / F$ & Clear cell & 11 months & Left & Alive for 2 years & $7 \mathrm{~cm}$ \\
\hline Nunes et al. [28] & $60 / F$ & Clear cell & $5 \mathrm{yr}$ & Left & Alive for 6 months & $4 \mathrm{~cm}$ \\
\hline Hardikar [18] & 29/M & Clear cell & Synchronous & Left & Alive for 2 years & NA \\
\hline Zhang et al. [17] & $67 / M$ & NS & $2 \mathrm{yr}$ & Left & Alive for 5 months & $11.4 \mathrm{~cm}$ \\
\hline Grewal et al. [15] & $53 / M$ & Clear cell & 2 months & Left & NA & NA \\
\hline Liu et al. [16] & 75/M & Papillary & Synchronous & Right & alive for 16 months & $9.9 \mathrm{~cm}$ \\
\hline Romao et al. [9] & $48 / \mathrm{M}$ & Clear cell & $11 \mathrm{yr}$ & Left & Alive for 2 months & $5.8 \mathrm{~cm}$ \\
\hline Agrawal et al [21] & $52 / \mathrm{M}$ & Clear cell & $3 \mathrm{yr}$ & Left & NA & NA \\
\hline Pal et al [24] & $54 / F$ & NS & Synchronous & NS & Unknown & NA \\
\hline Tatsuta et al. [25] & $69 / M$ & Clear cell & 17 months & Left & Alive for 11 months & $6 \mathrm{~cm}$ \\
\hline Murao et al. [11] & $72 / \mathrm{M}$ & NS & $10 \mathrm{yr}$ & NS & Alive for $1 \mathrm{yr}$ & NA \\
\hline Suzuki et al. [26] & $43 / M$ & NS & $7 \mathrm{yr}$ & NS & Alive for $9 \mathrm{yr}$ & NA \\
\hline Costantini et al. [27] & $41 / \mathrm{M}$ & Clear cell & $4 y r$ & Right & Alive for 27 months & $3.5 \mathrm{~cm}$ \\
\hline This report & $44 / F$ & Chromophobe & $12 \mathrm{yr}$ & Left & $\begin{array}{l}\text { Alive, and well now at } \\
12 \text { months post-resection }\end{array}$ & $5 \mathrm{~cm}$ \\
\hline
\end{tabular}

NS not specified, NA not available

histological appearance for the diagnosis of chromophobe RCC as advocated by some authors, a few panels of immunomarkers such as CD 117 and CK 7 may be used to confirm the diagnosis and distinguish it from the benign tumor, oncocytoma. We were, however, unable to perform immunohistochemical staining of the tissue blocks due to logistical difficulties-a limitation of this case report.

The prognosis of chRCC is reported to be good, with a 10 -year survival rate of $100 \%$ for localized (T1) chRCC [4]. However, metastatic chRCC has been shown to have an overall survival rate of 23.8 months in a study by Yip et al. In the same study, the overall response rate of metastatic chRCC to first-line targeted therapy (Sunitinib, Sorafenib, Everolimus) was 21\% [6]. Our patient would be followed up with this information on good prognosis in mind.

\section{Conclusion}

Splenic metastasis from RCC is uncommon, and rarer still from a chromophobe subtype of RCC. Surgical management of the metastasis is recommended, along with adjuvant radiotherapy to the splenic bed, and targeted therapy where available.

\section{Abbreviations}

RCC: Renal cell carcinoma; chRCC: Chromophobe type renal cell carcinoma; CT: Computed tomography; M: Male; F: Female; NA: Not available.

\section{Acknowledgements}

Not applicable.

\section{Author contributions}

SAA participated in the surgical operation and was a major contributor in writing the manuscript. AAS performed the histological examination of the kidney and spleen and was a major contributor in writing the manuscript. AOT was a member of the patient's management team and was a major contributor in writing the manuscript. OAF participated in the surgical operation and was a major contributor in writing the manuscript. IBU participated in the surgical operation and was a major contributor in writing the manuscript. JIN performed the histological examination of the kidney and spleen and was a major contributor in writing the manuscript. OBS participated in the surgical operation and was a major contributor in writing the manuscript. All authors read and approved the final manuscript.

\section{Funding}

None.

\section{Availability of data and materials}

The data used in preparing this case report are available from the corresponding author on reasonable request.

\section{Declarations}

Ethics approval and consent to participate

We received the permission from the Head of the Department of Surgery and written consent of the patient for this case report. 


\section{Consent for publication}

Written informed consent was obtained from the patient in this case report.

\section{Competing interests}

The authors declare that they have no competing interests.

\section{Author details}

${ }^{1}$ Department of Surgery, College of Medicine, University of Ibadan, Ibadan, Nigeria. ${ }^{2}$ Department of Surgery, University College Hospital, Ibadan, Nigeria. ${ }^{3}$ Department of Pathology, College of Medicine, University of Ibadan, Ibadan, Nigeria. ${ }^{4}$ Department of Pathology, University College Hospital, Ibadan, Nigeria.

Received: 22 September 2020 Accepted: 28 March 2021

Published online: 07 April 2021

\section{References}

1. Capitanio U, Bensalah K, Bex A, Boorjian SA, Bray F, Coleman J et al (2019) Epidemiology of renal cell carcinoma. Eur Urol 75(1):74-84

2. Showalter SL, Hager E, Yeo CJ (2008) Metastatic disease to the pancreas and spleen. Semin Oncol 35(2):160-171

3. Lindblad P (2004) Epidemiology of renal cell carcinoma i. Scand J Surg 93:88-96

4. Vera-Badillo FE, Conde E, Duran I (2012) Chromophobe renal cell carcinoma: A review of an uncommon entity. Int J Urol 19(10):894-900

5. Ismail A, Elmansy H, Shahrour W, Prowse O, Kotb A (2019) Very late locally recurrent chromophobe renal cell carcinoma: 15 years following radical nephrectomy for low-stage disease. J Surg Case Rep 8:1-2

6. Yip SM, Ruiz Morales JM, Donskov F, Fraccon A, Basso U, Rini Bl et al (2017) Outcomes of metastatic chromophobe renal cell carcinoma (chrRCC) in the targeted therapy era: results from the international metastatic renal cell cancer database consortium (IMDC). Kidney Cancer 1(1):41-47

7. Renshaw AA, Richie JP (1999) Subtypes of renal cell carcinoma: Different onset and sites of metastatic disease. Am J Clin Pathol 111:539-543

8. Comperat E, Armelle BD, Camparo P, Capron F, Charlotte F (2007) Splenic metastases. Arch Pathol Lab Med 131:965-969

9. Dos Santos Romao D, Horvat N, Castro Gonçalves M, Shigueaki Abe E, Blanco Dumarco R, Cesar Cavalcante Viana P, Machado MCC (2019) Isolated splenic metastases from renal cell carcinoma 11 years after surgery. Case Rep Med 2019(4):1-6. https://doi.org/10.1155/2019/7480479

10. Strum WB (1984) Remote recurrence of renal cell carcinoma. Urology 23(1):68-70

11. Murao Y, Kakiuchi T, Nakahashi H, Ashihara T (1987) A case of renal cell carcinoma metastasized to the spleen after 10 years of nephrectomy (in Japanese). Naika 59:582-584

12. Nabi G, Ansari MS, Seth A (2001) Early solitary splenic metastasis from adenocarcinoma of kidney. Indian J Urol 17(2):175-176

13. Ishida H, Konno K, Ishida J, Shirayama K, Naganuma H, Komatsuda T et al (1997) Isolated splenic metastases. J Ultrasound Med 16(11):743-749
14. Shuck-Bello CE, Morales-Montor G, Fernández-Orozco A, Vázquez-Ortega LS, Cantellano-Orozco M, Pacheco-Gahbler C et al (2007) Metástasis de carcinoma de células claras de riñón a bazo. [Clear cell carcinoma metastasis from kidney to spleen]. Rev Mex Urol 67(2):124-128

15. Kaur Grewal S, Doley RP, Roy K, Singla M, Malhotra M, Bawa AS et al (2016) Isolated splenic metastasis from clear cell renal carcinoma: a case report. Int J Surg Case Rep 29:44-46

16. Liu Z, Chow MW, Lua AH, Tan RB (2018) Rare isolated synchronous splenic metastasis in a patient with type II papillary renal cell carcinoma. AME Case Rep 2:9

17. Zhang L, Pasquale D, Le M, Patel R, Mehdi S (2015) Isolated splenic metastasis in a patient with two distinct genitourinary malignancies. $J$ Commun Support Oncol 13(2):229-230

18. Hardikar JV (2014) Synchronous solitary metastasis in renal cell carcinoma. IOSR J Dental Med Sci 13(3):111-113

19. Ielpo B, Mazzetti C, Venditti D, Buonomo O, Petrella G (2010) A case of metachronous splenic metastasis from renal cell carcinoma after 14 years. Int J Surg 8(5):353-355

20. Moir JAG, Sen G, Saif R, Haugk B, French JJ (2011) Isolated splenic metastasis from renal cell carcinoma: case report and review. Case Rep Gastroenterol 5(1):166-171

21. Agrawal A, Jatale P, Purandare N, Shah S, Rangarajan V (2014) Rare splenic metastasis of renal cell carcinoma detected on 99m Tc-MDP bone scan. Indian J Nucl Med 29(1):60-61

22. McGregor DH, Wu Y, Weston AP, McAnaw MP, Bromfield C, Bhattatiry MM (2003) Metastatic renal cell carcinoma of spleen diagnosed by fineneedle aspiration. Am J Med Sci 326(1):51-54

23. Kugel V, Dekel Y, Konichezky M, Baniel J, Livne PM, Koren R (2003) Unusual splenic metastasis from renal cell carcinoma. A case report and review of the literature. Pathol Res Pract 199(11):739-743

24. Pal KK, Guha D, Banerjee D (1995) Early splenic metastasis in a case of renal adenocarcinoma. J Indian Med Assoc 93(7):276-277

25. Tatsuta M, Shiozaki K, Masutani S, Hashimoto K, Imamura H, Ikeda M et al (2001) Splenic and pulmonary metastases from renal cell carcinoma: report of a case. Surg Today 31(5):463-465

26. Suzuki T, Sugaya K, Ogura Y, Shimoda N, Miyagata S, Nishizawa O et al (1996) A case of spleen metastasis of renal cell carcinoma (in Japanese). Hinyokigeka 9:1079-1081

27. Costantini M, Tuderti G, Minisola F, Pompeo V, Sentinelli S, Amoreo CA et al (2019) metachronous isolated splenic metastasis in a young patient with renal cell carcinoma: case report and literature review. Urology 127:13-18. https://doi.org/10.1016/j.urology.2019.01.007

28. Nunes TF, Szejnfeld D, Miiji LNO, Goldman SM (2012) Isolated metachronous splenic metastasis from renal cell carcinoma after 5 years. BMJ Case Rep. https://doi.org/10.1136/bcr-2012-00699

29. McKenney JK (2017) Kidney: tumors and tumorlike conditions Rosai and Ackerman's surgical pathology. Elsevier, Philadelphia, pp 1014-1047

\section{Submit your manuscript to a SpringerOpen ${ }^{\odot}$ journal and benefit from:}

- Convenient online submission

- Rigorous peer review

- Open access: articles freely available online

- High visibility within the field

- Retaining the copyright to your article

Submit your next manuscript at $\boldsymbol{\nabla}$ springeropen.com 